\title{
Integration of Abandoned Lands in Sustainable Agriculture: The Case of Terraced Landscape Re-Cultivation in Mediterranean Island Conditions
}

\author{
Michalia Sakellariou $^{1}$, Basil E. Psiloglou ${ }^{2} \mathbb{D}$, Christos Giannakopoulos $^{2}\left(\mathbb{D}\right.$ and Photini V. Mylona ${ }^{1, *(D)}$ \\ 1 Institute of Plant Breeding \& Genetic Resources, HAO-DEMETER, 57001 Thermi, Greece; \\ michsakellariou@yahoo.com \\ 2 Institute for Environmental Research and Sustainable Development, National Observatory of Athens, \\ Palaia Penteli, 15236 Athens, Greece; bill@noa.gr (B.E.P.); cgiannak@noa.gr (C.G.) \\ * Correspondence: phmylona@nagref.gr; Tel.: +30-231-047-1544
}

\section{check for} updates

Citation: Sakellariou, M.; Psiloglou, B.E.; Giannakopoulos, C.; Mylona,

P.V. Integration of Abandoned Lands in Sustainable Agriculture: The Case of Terraced Landscape Re-Cultivation in Mediterranean Island Conditions. Land 2021, 10, 457. https://doi.org/ 10.3390/land10050457

Academic Editors: Lucija

Ažman Momirski, Timmi Tillmann and Raimund Rodewald

Received: 17 March 2021

Accepted: 21 April 2021

Published: 24 April 2021

Publisher's Note: MDPI stays neutral with regard to jurisdictional claims in published maps and institutional affiliations.

Copyright: (c) 2021 by the authors. Licensee MDPI, Basel, Switzerland. This article is an open access article distributed under the terms and conditions of the Creative Commons Attribution (CC BY) license (https:/ / creativecommons.org/licenses/by/ $4.0 /)$.

\begin{abstract}
Agriculture terraces constitute a significant element of the Mediterranean landscape, enabling crop production on steep slopes while protecting land from desertification. Despite their ecological and historical value, terrace cultivation is threatened by climate change leading to abandonment and further marginalization of arable land imposing serious environmental and community hazards. Re-cultivation of terraced landscapes could be an alternative strategy to mitigate the climate change impacts in areas of high vulnerability encouraging a sustainable agroecosystem to ensure food security, rural development and restrain land desertification. The article presents the case study of abandoned terrace re-cultivation in the Aegean Island of Andros, using a climate smart agriculture system, which involves the establishment of an extensive meteorological network to monitor the local climate and hydrometeorological forecasting. Along with terrace site mapping and soil profiling the perfomance of cereal and legume crops was assessed in a low-input agriculture system. The implementation of a land stewardship (LS) plan was indispensable to overcome mainly land fragmentation issues and to transfer know-how. It was found that climate data are key drivers for crop cultivation and production in the island rainfed farming system. The study revealed that terrace soil quality could be improved through cultivation to support food safety and stall land degradation. In line with global studies this research suggest that cultivation of marginal terraced land is timely through a climate smart agriculture system as a holistic approach to improve land quality and serve as means to combat climate change impacts. The study also discusses land management and policy approaches to address the issue of agricultural land abandonment and the benefits gained through cultivation to the local community, economy and environment protection and sustainability.
\end{abstract}

Keywords: terrace landscape; land abandonment; climate-smart agriculture; sustainability; digital technologies

\section{Introduction}

The construction of artificial terraces on slopes for cultivation, known as terrace farming or terracing, is considered the only anthropogenic designed landscape that has a relief-modifying impact on all landscape factors in an area, as they improve rainfall absorbency, reduce soil erosion, smooth extreme summer temperatures, but also mitigate the risk of floods and forest fires [1]. The use of terrace landscape dates back in ancient years and it is tightly linked to early human settlement and primary agricultural activities $[2,3]$. Ever since, terrace construction has been extensively used across diverse landscapes to increase land productivity and to protect local environment and human infrastructure from severe mass movement and landslides $[4,5]$.

Cultivated terraces are a prominent feature of the Mediterranean agricultural landscape and the main cultivating system supporting primary production on the islands of the 
Aegean archipelago (Greece). Terracing is known to have multiple benefits on ecosystem services and human welfare, depending on land use and topography [6]. Estimation of the provided ecosystem services in terraced slopes over non-terraced slopes, revealed the prominent role of terracing in erosion control, runoff reduction, biomass accumulation, soil water recharge and soil nutrient enhancement [7]. All of these are vital to support agriculture sustainability, rural development and more importantly to lessen the effects of climate change on marginal lands, such as terraces.

During the last decades there has been a significant decline in land resources globally, mainly due to land degradation and desertification processes, which are taking place to an alarming rate. Climate change and human activities are major factors triggering ecosystem change, which is accompanied by a loss of biodiversity at different scales [8]. Prolonged drought seasons and dramatic reduction of water supplies are both important negative effects of climate change worldwide and near-future scenarios predict that the increasing frequency of extreme drought events will cause major crop yield losses threatening food security [9]. The significant loss of arable land in conjunction with the expected drop in crop yield and the upcoming increase of the global population ( 9 billion by 2050) are posing a serious threat on food security worldwide [10]. Therefore, combating land degradation and desertification to ensure global food security constitute the main challenges of the 21 st century. In order to achieve these goals, sustainable land management and policy interventions are needed to reduce the negative impacts of multiple stressors, restore ecosystems and safeguard their sustainable use. In Europe, the use of agricultural land is going towards two opposite directions: (a) abandonment of economically marginal, remote and upland areas and (b) intensification of farming practices in the restricted but productive lowland areas, both of which have serious implications for biodiversity and ecosystem services [11]. The drivers of agricultural land abandonment are manifold, depending on the economic, social and demographic situation of every region, the climatic conditions and topography [12]. Changes in the land-use of agricultural areas have a negative impact on the rural landscape and lead consequently to the marginalization of the abandoned land, while at the same time affect local food production, food security and the socioeconomic status of the area [13]. Marginal lands are defined as the abandoned agriculture lands of low productivity potential and reduced economic return, and sites with serious constraints for cultivation due to slope, soil structure and erosion phenomena [14]. Studies have shown that the countries of the Mediterranean basin are confronted with an alarming marginalization pace of their arable land, as the region is regarded a critical hotspot for land desertification and climate change in Europe [15-17]. Being a Mediterranean country, Greece faces the problem of increased desertification, with its islands being listed as areas of high desertification risk due to intense relief and low vegetation cover [18].

Despite the manifold advantages, limiting constraints of the terrace cultivation system, such as unfavorable cultivating conditions, high production cost and labor demand, along with a decline in rural population over the last decades, have led to the neglect of the terraces or even to complete abandonment $[19,20]$. The abandonment of terraced landscape increases environmental hazards, such as soil erosion, water runoff and biodiversity loss and consequently accelerates landscape degradation and marginalization [21]. Terraces must be well-designed, correctly built and well-maintained in order to provide ecosystem services [22]. Lack of appropriate maintenance or total abandonment of terraces lead to collapses of the structural features (stone-walls and benches) and increases geo-hydrological hazards through gully erosion and possible land sliding [23,24]. Thus soil loss and average runoff in poorly maintained terraces can be up to five times that of well managed ones [25].

At the same time valuable arable land is lost in areas where agriculture used to be the main economic activity, affecting significantly the socioeconomic conditions of local communities [26,27]. Therefore, re-cultivation of abandoned terraces could serve as an essential stategy to revitalize sustainable rural development, to restrain climate change hazards and land degradation of marginal lands. Over the last years, marginal lands have gained attention as an alternative potential for agriculture expansion that could help to 
increase food supply and avoid environmental and land degradation [28-31]. The economic and ecological success of the above scenario requires a specific landscape management plan, in order to fully exploit the dynamic of marginal sites. Thus restoration and recultivation of terraced landscape should be implemented with environmental impact considerations to avoid negative effects on terrain morphology as stated in the case of new terraced vineyards in Spain [32]. Moreover, innovative and sustainable production systems could be implemented collectively to achieve smart crop cultivation, stimulating in parallel ecosystem services conservation and strengthening. In that regard climate smart agriculture (CSA) could have a key role to increase production of marginal lands in an ecologically and profitably sustainable way and secure farmers' economic interest [33]. Building farmers' adaptive capacity is central to CSA, empowering an effective feedback to long-term climate change and associated manage risks [34,35]. In turn CSA combines tested practical techniques, such as conservation agriculture, crop rotation, mulching, intercropping and improved water management with innovative technologies, such as precise weather forecasting, early warning systems and risk assessment models [36] and crop phenotyping [37]. On the other hand, agriculture in the Aegean islands is vulnerable to climate change due to limited water resources and increased periods of heat stress, entailing for a close linkage of weather forecast and monitoring for terraced lands cultivation.

The present study aimed to assess the potential of abandoned terraces to serve as green infrastructures through cultivation to alleviate climate change effects and land abandonment. An understanding of the challenges and constraints associated with agricultural land use and management in climate change times will assist to abate land abandonment and degradations for sustainable improvement. Yet, there are scattered and limited evidence of climatic conditions, soil resources of abandoned or cultivated terraced lands in the East Mediterranean islands. Thus, the role of these parameters in agriculture still remains obscure. The study addresses these knowledge gaps in a systematic research approach. Establishing a meticulous meteorological network of stations along with soil profiling and position mapping of terraced fields, recultivation assessment, functioning and effects are explored. The ultimate objective is to contribute evidence to policies to address terraced lands re-cultivation implementing a climate smart agriculture approach for rural agroecological sustainability and development.

\section{Methods}

\subsection{Study Area}

The island of Andros belongs to the Cyclades island complex of Aegean Sea in Greece and it is characterized by intense relief with low vegetation cover, a typical landscape type for the majority of Aegean Sea islands. Terrace cultivation has been for years the main cultivating system, supporting primary production on the island. However, over the last decades agricultural activity has been significantly reduced and the majority of the terraces were abandoned. Land fragmentation and high cultivation costs were the main reasons of land abandonment in the area. However, the majority of teracce fields on the island are well-maintained and minimum restoration work was applied where needed. The selection of the terraces was based on their topography and cultivation history (terraces that remained uncultivated for more than ten years). The accessibility of agricultural machinery was also an important criterion of terrace fields selection. The intervation site is composed of discontinious parcels; each terrace field consisted of 3-5 individual parcels. Terraces have no irrigation system or access to irigation. As terraces remaied uncultivated for years, low vegetation (mainly shrubs) removal was performed in the intervation area. Terraces that included trees were excluded, as removal of trees is under national regulation, requiring special permits.

\subsection{Study Implementation}

A total area of 45 hectares of terraced fields was engaged in re-cultivation. Thirteen meteorological stations were placed near the cultivation sites in order to monitor micro- 
climatic conditions in the area (Figure 1). This is the first large-scale establishment of a meteorological network on the island, as until recently there was only one station in the north-west part of Andros providing basic data for navigation purposes.

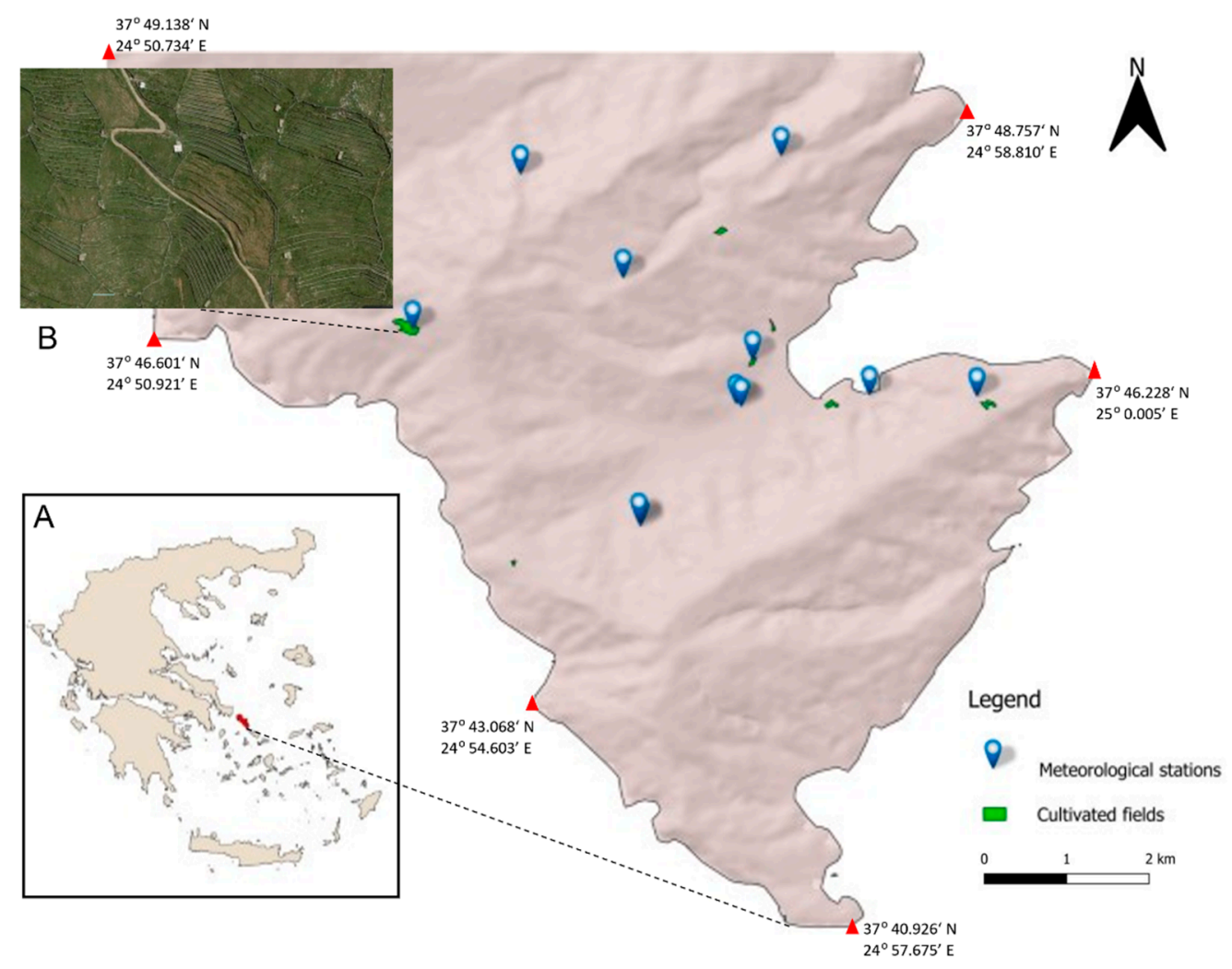

Figure 1. Map of the study area in Andros Island. The geographic location of Andros island is depicted (in red) on the map of Greece (A). The metereological stations and intervention sites are depicted by blue and green signs, respectively. A terraced site is also shown (B). The map was developed using the QGIS ver.3.10.6 open source GIS software and the 3D digital elevation model EUDEM ver.1.1 from the European Copernicus project. Coast line coordinates are indicated by red triangles. Map scale 1:1,000,000.

In particular, one fully automatic weather station with remote-access has been installed on the roof of the Moustakeio building at Korthi, South East Andros $\left(\varphi=37^{\circ}\right.$ $44.775^{\prime} \mathrm{N}, \lambda=24^{\circ} 55.658^{\prime} \mathrm{E}$, height $=215 \mathrm{~m}$ a.m.s.1.), completed with a central CR310 data-logger by Campbell Scientific Ltd. and a number of high precision sensors covering all meteorological parameters such as air temperature $\left({ }^{\circ} \mathrm{C}\right)$ and relative humidity $(\mathrm{RH})(\%)$, atmospheric pressure $(\mathrm{hPa})$, precipitation $(\mathrm{mm})$, wind speed $(\mathrm{m} / \mathrm{s})$ and direction (deg.), and finally incoming solar radiation intensity $\left(\mathrm{W} / \mathrm{m}^{2}\right)$ received in an horizontal surface. The continuous data-series of the automated station at Moustakeio stretches back to July 2018, consisted of 1-min averages of 10-s samples. Hourly, daily and monthly data were then generated for further analysis (see Supplementary Materials).

Additionally, twelve small autonomous battery backup stations from onset, model HOBO MX2302 T/RH loggers, with bluetooth low energy communication abilities, covering only air temperature $\left({ }^{\circ} \mathrm{C}\right)$ and relative humidity $(\mathrm{RH})$ at $2 \mathrm{~m}$ height, have been installed inside a solar radiation shield at abandoned or cultivated terrace sites in the south part of the island, reporting with a high-resolution of 10-min time step, micro-climatic data for the study needs. These stations are not remotely accessible and data are downloaded manually during periodical visits to Andros Island.

In order to compare the readings for temperature and relative humidity between the two types of stations, the MOUSTAKEIO site has been selected where both types of stations operate. Thus, Figure 2 represents mean daily values of air temperature from the 
Moustakeio central station and the difference from HOBO sensor's measurements for the available period: 1 July 2018 to 17 December 2020. Differences in temperature generally do not exceed $\pm 0.5^{\circ} \mathrm{C}$. For the same period, RH measurements were also analysed for both stations at Moustakeio, and the plot is given in Figure 3. Differences in humidity between the two types of stations generally do not exceed $\pm 2 \%$.

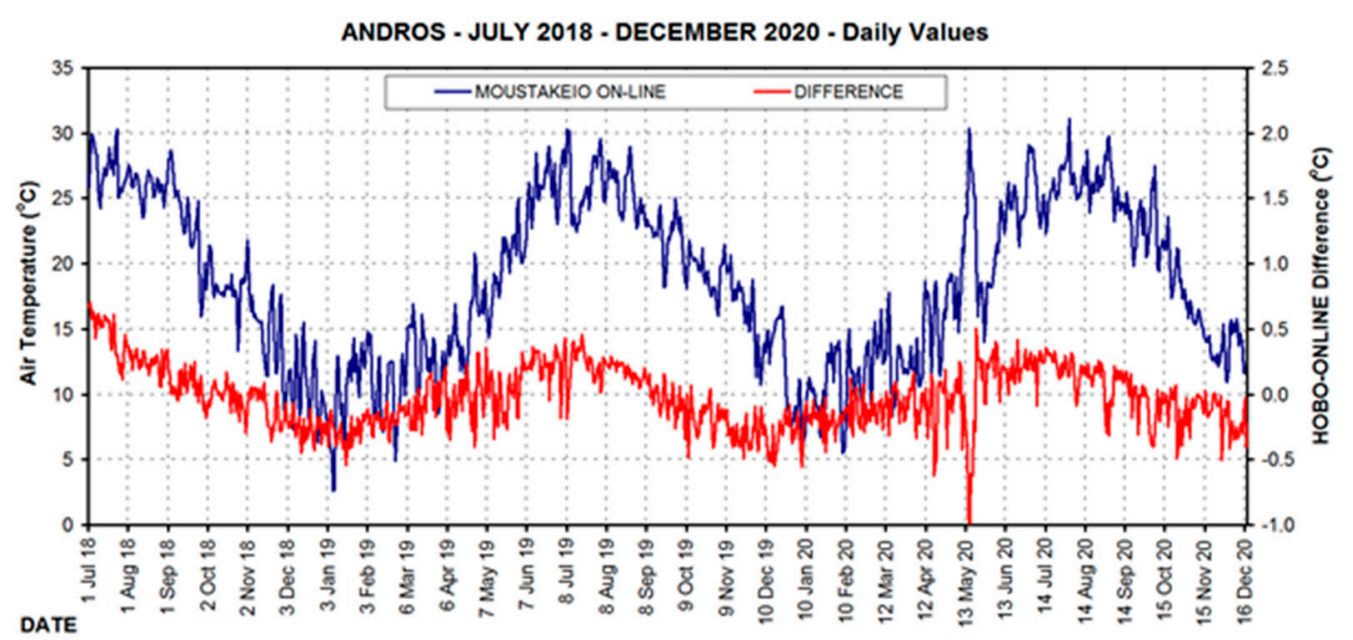

Figure 2. Plot of daily mean values of air tempertatures at Moustakeio central online station (blue line) with the differences of the smal HOBO sensor from the central on-line station (red line).

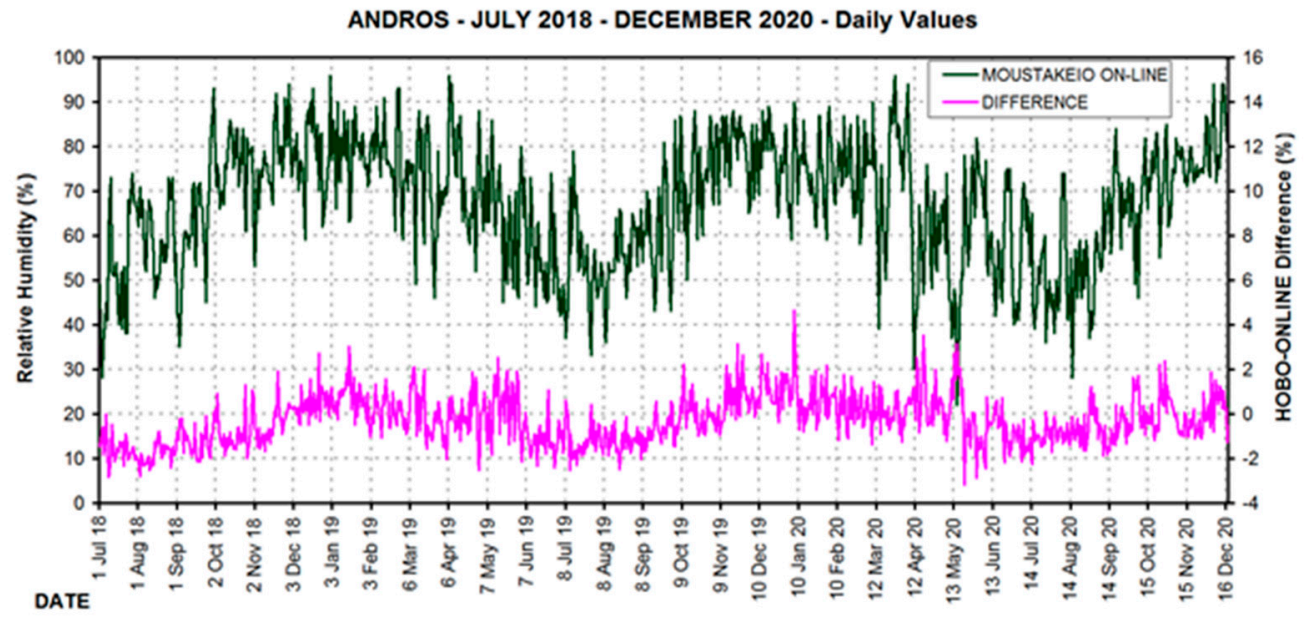

Figure 3. Plot of daily mean values of relative humidity at Moustakeio central online station (green line) with differences of the smal HOBO sensor from the central on-line station (purple line).

During the summer period, the HOBO station shows slightly higher values of temperature and lower values of relative humidity than the online station, which is attributed to the fact that the online station is at a better ventilated position on top of a building where typical summer etesian winds are strong in the island of Andros. The pattern is reversed in winter since the $\mathrm{HOBO}$ station is surrounded by seasonal wild vegetation something that does not occur at the building terrace where the online station resides. Hence, in the wetter, cooler period of the year, the $\mathrm{HOBO}$ station shows higher relative humidity levels and lower temperature values. However, these differences are considered minor and insignificant.

Therefore, emphasis was given on getting site-specific meteorological data, which are critical in a climate-smart agriculture system in order to provide precise weather forecasting, early warning systems and risk assessment models. Resources management was based 
on microclimatic conditions (e.g., rainfall accumulation, solar radiation and wind speed) during the cultivation period.

Another important parameter for the successful re-cultivation of terraced landscapes was the selection of appropriate crops and varieties, which must be well-adapted to the indigenous climate and landscape conditions. Therefore, the cultivation plan of the abandoned terraces focused on the use of local landraces, which are considered valuable genetic resources preserving and promoting biodiversity, and support production of local products. The cultivation plan included local landraces of cereals (barley) and legumes (vetch). Barley (Hordeum vulgare) landraces were selected due to their high tolerance to drought conditions, compared to wheat and other cereals. Legumes, such as vetch (Lathyrus sp.), provide protein-rich food and feed, but more importantly, legumes enhance soil fertility due to their symbiotic ability of nitrogen fixation. The selection of the crops was conducted according to island's agricultural tradition, as cereals and legumes have been extensively cultivated in terraced fields. As there were no site-specific meteorologiacal data available before the intervention, weather monitoring was crucial to assess the perfomance of the crops during the growing seasosns. The selected crops were introduced in rainfed cropping schemes of low-input farming.

Due to lack of geomorphological map and extensive field surveys on the island, the condition and structure of terraces top soil is unknown. Therefore, soil analyses were conducted to study important soil features, such as nutrient status, soil-type and organic matter content $(\%)$. Soil sampling was perfomed in terraces prior and after cultivation to assess soil profile and chemical analyses of nutrient and organic matter content. Moreover, soil analyses were conducted to assess the effect of crop cultivation on soil fertility and for further resources management plan. A chemical analysis of macro and micro element content was used to assess the nutrient value of the produced crops. A commercial cultivar of barley was incorporated as a reference crop to assess both performance and nutrient content of the crop.

Additionally, a land stewardship (LS) enterprise was established as a necessary measure to overcome land fragmentation issues and lessen production costs in order to create a sustainable terrace cultivation system. The LS enterprise was used as a leverage to encourage active participation of local bodies and land users in terrace re-cultivation and new technologies.

\section{Results}

Data collected from the meteorological stations were further used for the development of local weather forecast models, but also in the cultivation operation plan for better utilization of natural resources. More precisely, solar radiation and rainfall frequency and distribution throughout the growing season were utilized to determine the kind of crops to be cultivated in the area. Cumulative precipitation $(\mathrm{mm})$ per month for three growing seasons (2018-2021) in Andros Island is presented in Figure 4. According to the graph, there is significant rainfall during the period October to April, which coincides with the critical growing stages of the winter crops. Sowing season for barley in Eastern Mediterranean is usually late October to early November and soil humidity at that stage is needed to facilitate the preparation of the fields (tillage), but most importantly rainfall is critical to ensure high germination rate of the crop. Winter legumes are sowed in November and benefit also from the autumn rainfalls during that time. Another critical developmental stage for both crops is the seed filling stage (April to early May), when the need for water supply is high for seeds to increase in size and weight. Total precipitation in Andros Island during April (Figure 4) was high enough in growing seasons 2018-2019 and 2019-2020, allowing thus, crops to take full advantage of the available "green water" (rainfall water that is stored as soil humidity). 
ANDROS - MOUSTAKEIO - JULY 2018 - MARCH 2021 - Monthly Values

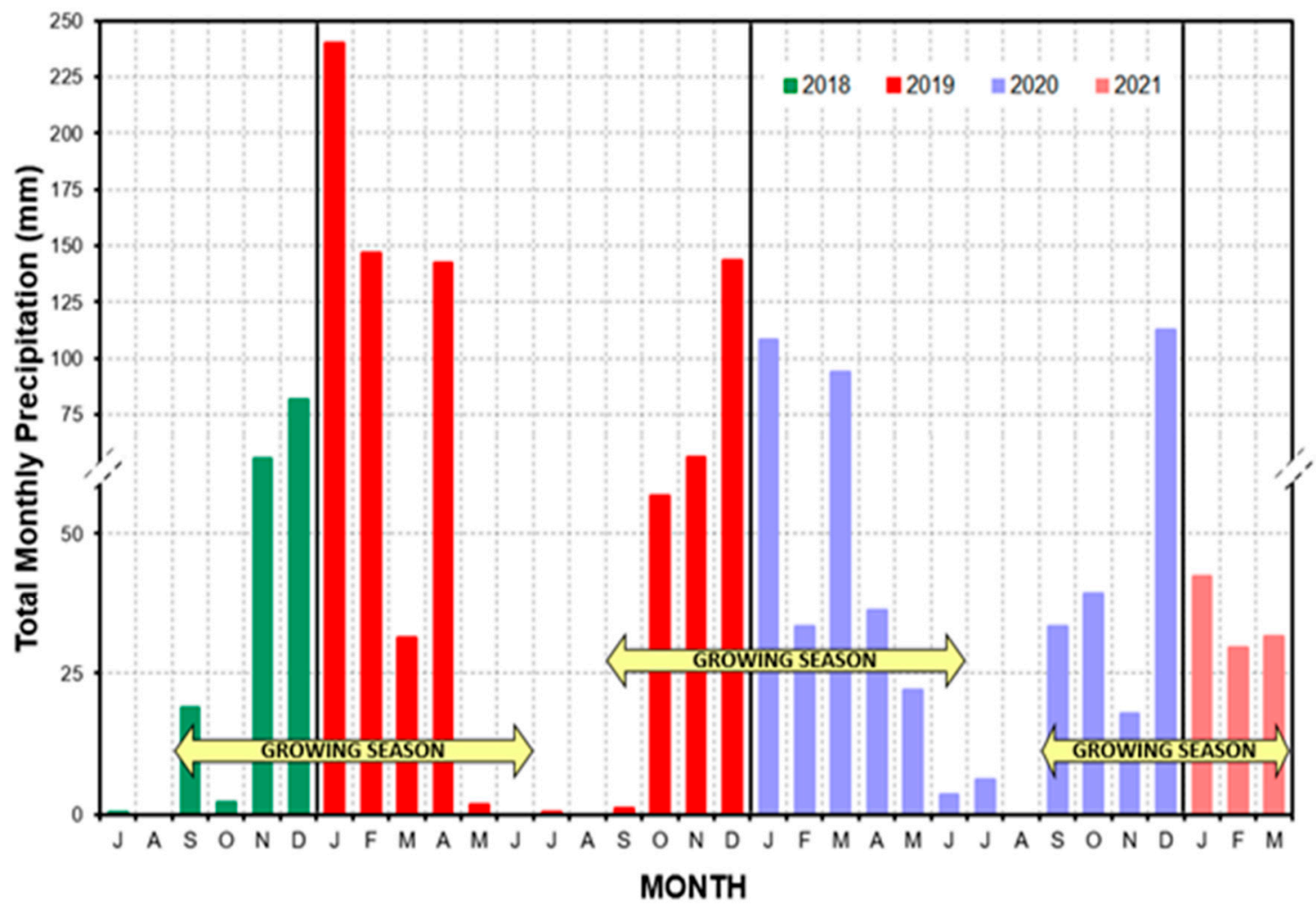

Figure 4. Total precipitation (mm) per month for three cultivating periods (2018-2021) in Andros Island.

Average solar radiation $\left(\mathrm{W} / \mathrm{m}^{2}\right)$ per month for the three growing seasons is presented in Figure 5. The highest values are evident between May and September (with a peak during summer months), which is a typical climatic condition for the countries of the Mediterranean basin. High solar radiation during that period, accompanied by hot temperatures, is combined also with a drop in precipitation (Figure 4), resulting in a thermal dry environment. Under these circumstances, crop cultivation is challenged. However, winter crops such as cereals and legumes are positively affected by these climatic conditions, as hot and dry weather is essential for the maturation of the seed until harvest time (June to early July). It becomes obvious that the suggested crops can be successfully cultivated in Andros Island under a low-input rainfed agriculture system, taking full advantage of the available natural resources. Hence the establishment of a meteorological network is essential to a smooth transition of agriculture to digitization suppling valuable data, helping farmers, improving practices and decision making. 


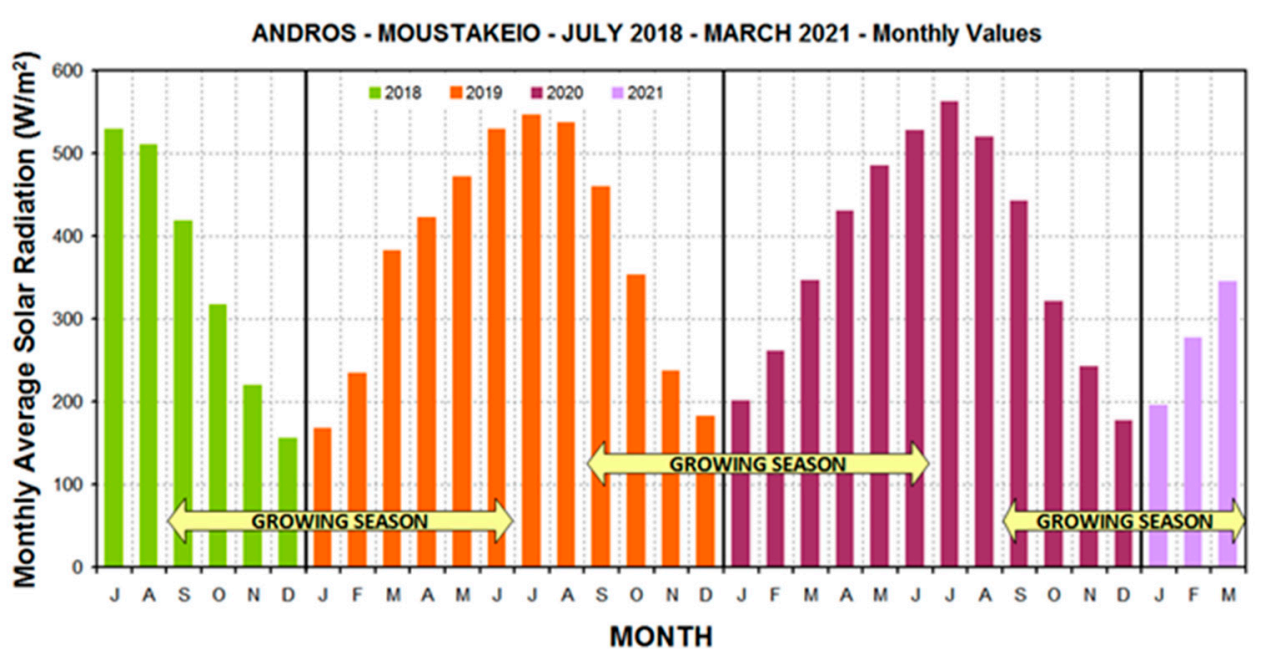

Figure 5. Average solar radiation $\left(\mathrm{W} / \mathrm{m}^{2}\right)$ per month for three cultivating periods (2018-2021) in Andros Island.

In order to estimate the quality of the produced crops, the concentration of macro and micro nutrients was tested in both barley and vetch landraces. Chemical composition (mean values) of the crops is presented in Table 1. Local landrace of barley had higher concentration of all macro and micro elements, compared to the reference barley crop. The chemical analysis of vetch landraces showed a high concentration of $\mathrm{N}$, as expected for legumes. High concentrations of $\mathrm{Fe}, \mathrm{Mg}, \mathrm{Mn}, \mathrm{K}$ and $\mathrm{Zn}$ add extra nutrient value to the crops (Table 1). The results show that local landraces are characterized by good quality of the harvested product and could be used to a climate-smart agriculture system.

Table 1. Chemical analysis of macro and micro elements of barley (Hordeum vulgare) and vetch (Lathyrus sp.) landraces.

\begin{tabular}{|c|c|c|c|c|c|c|c|c|c|c|c|}
\hline & $\begin{array}{c}N \\
(\%)\end{array}$ & $\begin{array}{c}P \\
(\%)\end{array}$ & $\begin{array}{c}K \\
(\%)\end{array}$ & $\begin{array}{c}\mathrm{Ca} \\
(\%)\end{array}$ & $\begin{array}{l}\mathrm{Mg} \\
(\%)\end{array}$ & $\begin{array}{l}\mathrm{Na} \\
(\%)\end{array}$ & $\begin{array}{c}\mathrm{Zn} \\
(\mathrm{ppm})\end{array}$ & $\begin{array}{c}\mathrm{Fe} \\
(\mathrm{ppm})\end{array}$ & $\underset{(p p m)}{\mathrm{Cu}}$ & $\begin{array}{c}\text { Mn } \\
(\mathrm{ppm})\end{array}$ & $\begin{array}{c}\text { B } \\
(\mathrm{ppm})\end{array}$ \\
\hline Barley landrace & 1.69 & 0.41 & 1.98 & 0.33 & 0.10 & 0.36 & 27.47 & 81.50 & 6.59 & 40.23 & 2.99 \\
\hline Barley cultivar & 1.19 & 0.24 & 1.07 & 0.13 & 0.05 & 0.05 & 24.01 & 45.90 & 4.99 & 31.96 & 2.83 \\
\hline Vetch landrace I & 3.38 & 0.63 & 2.37 & 0.84 & 0.23 & 0.10 & 56.54 & 198.82 & 12.69 & 52.24 & 2.75 \\
\hline Vetch landrace II & 3.25 & 0.50 & 1.94 & 0.64 & 0.19 & 0.06 & 50.80 & 255.69 & 13.75 & 52.94 & 2.75 \\
\hline
\end{tabular}

Soil nutrient status and type (soil composition) of the recultivated terraced fields was defined by chemical analyses in order to develop a spatial profile for each field engaged in the study. These profiles are further used for monitoring crop impact on soil properties, but also in decision-making process regarding input management. Soil profiles according to their composition in sand $(\mathrm{S} \%)$, clay $(\mathrm{C} \%)$ and silt $(\mathrm{Si} \%)$ are presented in Table 2 . Soil electrical conductivity $(\mathrm{Ec})$ and $\mathrm{pH}$ were also measured. The majority of the tested soils was classified as sandy-loam (SL), expect terrace 6 and 7, which were classified as loamy-sand (LS) and loam (L) respectively (Table 2). In soil electrical conductivity is an indicator of nutrient availability and it is associated with soil fertility. Results show that Ec of terrace soils is within the optimal range (110-570 milliSiemens/m). However, high values of Ec indicate excess amount of salts in the soil and may hinder plant growth. 
Table 2. Soil texture (sand $\%$, clay $\%$ and silt $\%$ ), soil pulp $\mathrm{pH}$ and electrical conductivity (mS/m) of seven selected terrace fields.

\begin{tabular}{ccccccc}
\hline Terrace & Soil Type & $\mathbf{S} \%$ & $\mathbf{C} \%$ & $\mathbf{S i} \%$ & $\mathbf{p H}$ & Ec $(\mathbf{m} \mathbf{\%} / \mathbf{m})$ \\
\hline $\mathbf{1}$ & SL & 68 & 10 & 22 & 6.16 & 415 \\
$\mathbf{2}$ & SL & 60 & 18 & 22 & 6.32 & 578 \\
$\mathbf{3}$ & SL & 74 & 6 & 20 & 5.75 & 410 \\
$\mathbf{4}$ & SL & 68 & 8 & 24 & 5.85 & 421 \\
$\mathbf{5}$ & SL & 58 & 12 & 30 & 6.83 & 520 \\
$\mathbf{6}$ & LS & 84 & 2 & 14 & 6.95 & 754 \\
$\mathbf{7}$ & L & 50 & 16 & 34 & 6.33 & 444 \\
\hline
\end{tabular}

The impact of crop cultivation on soil fertility was assessed through soil organic matter (SOM) content (\%). Organic matter was measured before cultivation, in terraced fields, which remained uncultivated for more than ten years, and after cultivation and incorporation of crop residues in soil. The calculation of increase (\%) in soil organic matter was based on preliminary results from two growing seasons (2018-2019 and 2019-2020). Results showed that organic matter content was significantly increased after cultivation, suggesting the beneficial impact of crop cultivation on soil properties. Terraced fields $1-5$ were cultivated with barley, while terraces 6 and 7 with vetch (Figure 6 ). Terraced fields 3 and 6, which had the lowest increase in organic matter content, had also the highest content of sand (S\%), according to soil analyses results (Table 2). Sandy soils are generally considered poor soils of low organic matter content, cation exchange capacity (CEC) and therefore of low nutrient retention capacity [38]. High Ec value of terrace 6 may indicate salinity problems, which also affect negatively soil fertility.

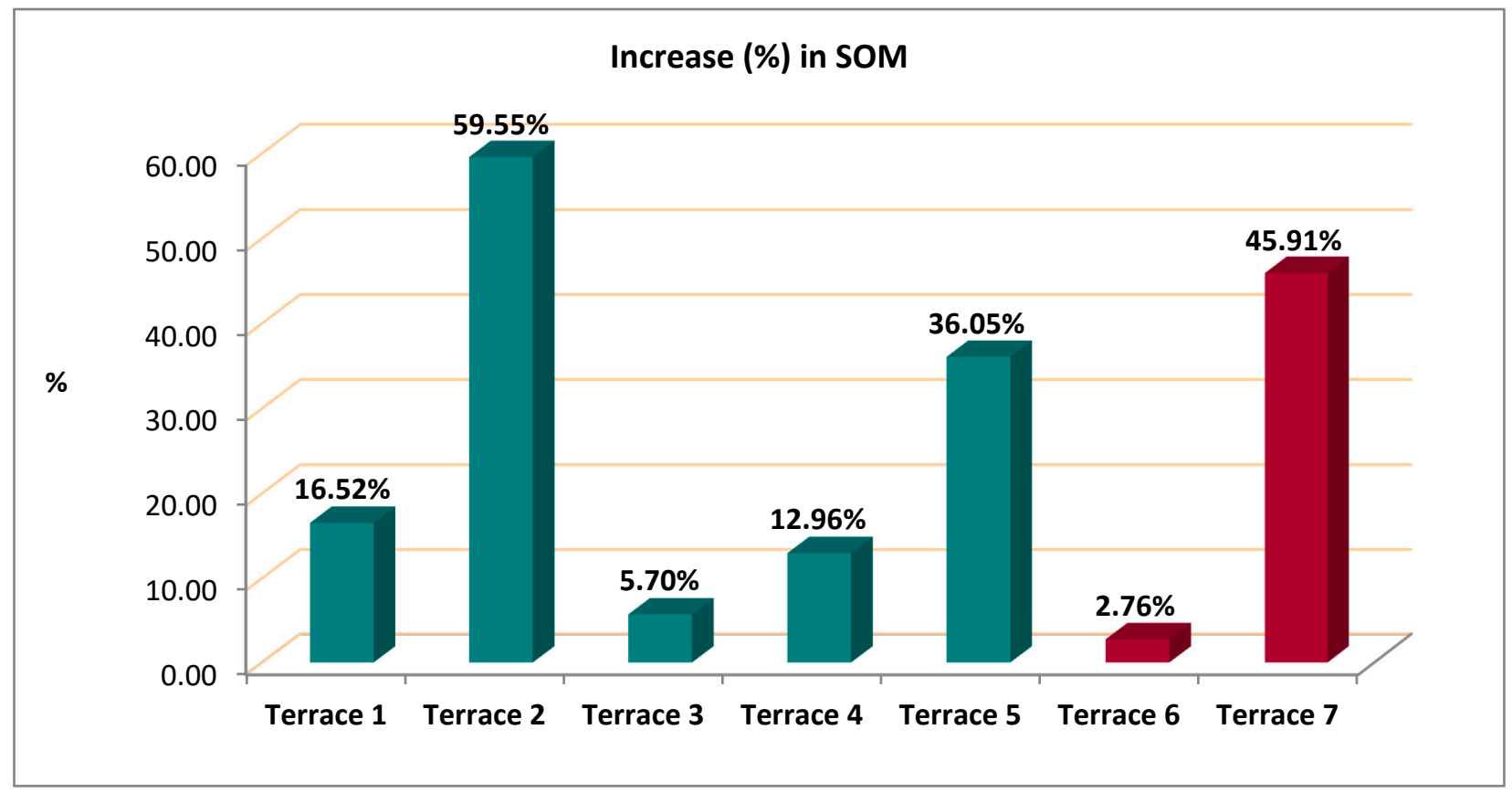

Figure 6. Increase in soil organic matter (SOM) content (\%) in selected terraced fields after crop cultivation. Terraces 1-5 were cultivated with barley (Hordeum vulgare), while 6 and 7 with vetch (Lathyrus sp.).

\section{Discussion}

The functional restoration of the terraced landscapes as an agricultural area of high natural value, aims to preserve valuable land resources by mitigating the negative effects of climate change, which accelarate land degradation and desertification phenomena. The Mediterranean landscape with its steep slopes and intense relief is prone to soil erosion 
due to long dry periods followed by heavy and abrupt erosive rainfalls [39]. Over the years terracing was proven to be an ideal agricultural method for crop cultivation in slopping landscapes, creating arable land where needed, while at the same time protects soil from erosion and runoff phenomena through water absorption and moisture conservation [40]. Changes in land use during the last decades in the countries of the Mediterranean have led to vast agricultural land abandonment, including terrace landscapes [41]. Hence terraces that are not maintained and remain uncultivated, fail to protect soil against water runoff, flooding and landslide phenomena due to stone wall collapse. Abandonment of terrace landscape can have serious implications on the environment and cause structural damages, when triggered by severe rainfall, as happened in the case of Liguria region (Italy) in 2014 [42]. Studies have shown that soil erosion and land degradation process is accelerated in terraces that lack maintenance and vegetation cover, compared to well-maintained ones with crop cultivation or dense wild vegetation [43-45]. Dry stone walls are paramount to reduce slope length, trap erosion sendiments and reduce soil run-off. Hence the selection of suitable materials and construction techniques constitute principal parameters of terrace stone walls restoration and function for land protection [46]. Given that the majority of dry stone walls in Andros terraced fields are in good condition, reintegration to cultivation prevailes to safeguard land as a market good and added value to agriculture and sustainable environment performance and protection.

As terraced landscape is usually characterized by great heterogeneity, the operational cultivation plan to be followed should be site-specific, based on the peculiarities of each area. Therefore, knowledge of the soil profile, including nutrient status, soil-type and organic matter content, is considered critical in the decision-making process of crop selection, and in the management of integrated farming systems and natural resources. Geomorphological maps and spatial surveys are fundamental basis for management of terraced landscape and hazards assessment [47]. Additionally, remote sensing techniques (e.g., LiDAR) and geographical information system (GIS) are implemented in the mapping of terraced landscape to assess slope instabilities [48]. Spatial mapping of terraced landscape in Andros Island is still ongoing and once completed will constitute a useful tool for land management policy. Soil analyses in sampling areas provided a first assessment of top soil condition (soil structure and composition). Primary results from two cultivating seasons (2018-2019 and 2019-2020) in Andros terraced landscape showed an increase in soil organic matter content after cultivation, suggesting the positive effect of crop residues input and decomposition in soil, by increasing soil organic carbon (SOC), and thus enhancing soil fertility $[49,50]$. However, as the experimentation is still ongoing, the role of crop cultivation in soil fertility and climate change mitigation needs to be further investigated.

The study indicated that annual precipitation rate is a major driver of crop selection and performance in the rainfed terraced system. Results showed that winter crops, such as cereals and legumes can be cultivated in a rainfed system, taking full advantage of the annual rainfall distribution in Andros Island during the critical crop developmental stages. Detailed meteorological data collected by the extensive network of the meteo-stations during the growing seasons (2018-2021), displayed a period of high precipitation on the island (October to early May), followed by a hot and dry period (June to September). Barley (Hordeum vulgare) landraces was selected for cultivation of abandoned terraces due to its significant drought tolerance compared to other cereals [51-53]. Notably barley landraces bear many desirable traits counting abiotic stress tolerance, nutrient use efficiency and crop quality characteristics, and therefore are excellent germplasm material for a low-input agriculture system [51]. Nonetheless barley crop productivity is dependent on water supply during the critical developmental stages, after sowing for successful germination rate (October to November) and during seed filling stage (April until early May), which both coincide with the high precipitation period on the island. Studies have shown that the environment (climatic and soil conditions) plays a major role in the determination of grain size and weight in barley. Drought has a more significant negative effect on grain growth, compared to the effect of high temperature [54,55]. Low rainfall during 
the grain filling period, and thus less soil water availability, results in lower grain yield and dry matter accumulation in barley [56], affecting the final yield of the crop. Given the precipitation levels and monthly distribution in Andros Island, it is suggested that barley cultivation can be sustained under a rainfed system, taking full advantage of the microclimatic conditions. In addition, reduction in post-anthesis radiation reduces grain weight in barley and increases the heterogeneity of grain weight, affecting the final yield of the crop [57]. Measured solar radiation in Andros during the post-anthesis period was sufficiently high, ensuring good photosynthetic rate of the crops.

Vetch (Lathyrus sp.) is traditionally cultivated in the Aegean islands as a legume crop used for the production of local products commonly known as "fava". Its cultivation is also favored under the climatic conditions described above. Moreover, cultivation of legumes is known to have a beneficial effect on soil structure and fertility due to their symbiotic ability to fix nitrogen, and it is recommended for the enhancement of poor soils [58,59], and in rotation systems. Primary results showed that SOM content (\%) was increased in terraces cultivated with vetch. The increase of SOM content after cultivation of legumes and cereals in abandoned terraced fields indicate that the soil composition could be improved. Consequently, it improves the retention capacity of soil nutrients and humidity for better crop development. Undoubtedly these characteristics could be further improved and monitored following CSA practices such as intercropping, rotation and limited tillage [35]. Re-cultivation of abandoned terraced fields have unraveled constraints and knowledge gaps (i.e., precipitation rate, climatic data, soil features, etc.) that could impede agriculture. On the other hand, implementation of a CSA system as a holistic approach, combining agricultural practices and technological innovations to ensure crop production and enhance resilience to climate change is urgently needed. In this regard information communication technologies (ICT) could enable the transition stimulating a precision agriculture system for climate smart landscapes. Thus, local climate information services are crucial in defining critical stages of crop development that require efficient use of natural resources, counting "green water" as precipitation rate, temperature extremes and early warning for risk management. Therefore, awareness and training of farmers and crop stakeholders is timely and crucial to enhance utilization of the above information in farming systems of marginal lands.

Although the agricultural sector in the island regions of Greece (Ionian, North and South Aegean) is smaller compared to the mainland regions, the impact of climate change has severe environmental and economic dimensions. Strengthening agriculture in these islands is very important to secure food safety at a local level, regarding issues that arose recently from the COVID-19 pandemic, but also because islands are major tourist destinations and thus have a large demand of agricultural products. This support should be focused on mitigating water stress, which is the main restriction of crop cultivation on the islands [60]. Land fragmentation and topographic issues of the Mediterranean islands pose limitations on crop production increase and therefore, land use intensification of terrace landscapes should aim on the production of high added value crops. Chemical analyses of the crops showed that both barley and vetch landraces had good quality characteristics when grown under low-input farming system. The dynamic of such crops should be further exploited for the production of novel food products of high quality and nutrient content, addressed to consumers with specific dietary needs. Biofortification of staple foods, such as barley and legumes, could be an alternative strategy for the enhancement of the primary sector and economy via the production of innovative products [61]. Apart from human consumption, cereal and legume crops are also suitable for animal feed, supporting livestock activity on the island and the production of a vast variety of local dairy products. In addition, legume crops provide important pollination services and enhance apiculture [62,63], which is a significant production sector in the Aegean Islands. Therefore, sustainability of the primary sector on the island could be achieved in the context of a green-economy development, with low-input agriculture, reduced carbon emissions, 
increased efficiency of resources usage, enhanced pollination and ecosystem services and economic growth [64].

One of the main social drivers of land abandonment is the shift in habitation patterns from rural to urban societies in many parts of Europe. Globalization of agricultural markets, low income, labor requirements, topography and loss of motivation for farming have forced farmers to abandon their land and migrate to bigger cities for better opportunities [65]. Those who remained in marginal areas usually retain their land as family property and have become part-time farmers in the parallel with another occupation, or they are retired farmers with no identified succession and therefore prone to agriculture and land abandonment [66]. Land tenure and ownership or rural land rental, combined with land fragmentation and restricted resources often pose a significant obstacle to appropriate management and rural development. The negative effects of fragmentation mainly arise from the lack of sufficient investments by individual farmers on technological equipment and agriculture practices (e.g., weather forecast, drainage, irrigation and soil improvement), resulting in significant decline of crop production and profit [67]. Thus, younger generations abandon farming and more arable land remains uncultivated. The disadvantages of land fragmentation can be overcome through a collaboration system between farmers, stakeholders and local authorities, which will encourage active participation of local bodies and land users in a sustainable land management plan and will revitalize the local society and economy $[68,69]$. The land stewardship (LS) system could be a successful approach for a holistic management of abandoned and marginal areas. The LS system could serve as a leverage of new technologies and digitization implementation in the agriculture of marginal lands by helping farmers to work more precisely, efficiently and sustainably. Through the implementation of LS plan the cost-input resources are shared between participants, novel technologies and equipment become accessible to all, farmers are trained to increase their capacity, crop production becomes cost-effective, economic revenue is increased and finally sustainable management of wider landscape is achieved, providing thus, motivation to farmers to get involved in crop cultivation [70]. Moreover, the data-driven insights can improve decision-making and practices and enhance environmental performance while making agriculture more attractive to younger generations, reduce remoteness problems and increase access to services. In Andros Island the perception of local community regarding agricultural terrace landscape is high and people are interested in maintaining terraces as a valuable feature of local environment. The reasons for ceasing crop cultivation were mainly cost-related, due to high individual financial investment requirements. Land fragmentation resulting in higher transaction costs in combination with lack of modernization and low farmers' income, are recognized among the major drivers of terrace abandonment [71]. The implementation of an LS plan on the island managed to resolve issues regarding land fragmentation and collective cultivation. Adequate machinery was bought to fit the narrow terrace parcels and crop production was upgraded, lessening individual cost. Thus, LS could serve as a leverage to halt land abandonment and instigate use of novel farming systems to alleviate the climate change effects for environment protection and rural sustainable development.

Despite its indisputable ecological value, terraced landscape is also an important agricultural heritage system of great aesthetic and cultural significance. Terraces are considered traditional landscapes and their conservation and management concept is included in the international globally important agricultural heritage systems (GIAHS) program, launched by Food and Agriculture Organization (FAO) [72]. National policies are targeted on preserving such agricultural heritage sites around the world, but also promote them as touristic attractions, which maintain their traditional and historical character [73,74]. A survey on terraced landscape perception in the Chianti region (Italy) showed that tourists clearly prefer visiting a traditional landscape, which is comprised of a mosaic of agricultural patches with dry-stone terraces and forests [75]. In Greece the majority of island terraces are neglected and only part-time farmers acknowledge the productive, ecological, aesthetic and historical value of terraces, although terrace 
farming still remains hard-work. In this context, terraces appear to have lost their original functional role in agricultural production and they remain as a decorative element of the Mediterranean landscape [76]. However, in Andros Island the majority of terraces is well maintained and could be a pole of touristic attraction, incorporated in the island's quality certified $100 \mathrm{~km}$ hiking route from European Ramblers Association (https:/ /www.eraewv-ferp.org/lqt/, (accessed on 5 April 2021)). Tourists will have the chance to enjoy the aesthetic value of the landscape, but also to come in touch with a sustainable agriculture system of traditional crops. Terraces form a valuable part of the national landesque capital and therefore, national government policy should be updated and measures are urgently needed for the preservation of the island terraces, as elements of traditional landscape heritage and of rural sustainability.

\section{Conclusions}

Agricultural terraces constitute a valuable element of the Mediterranean landscape, which can be used as an alternative strategy to mitigate climate change effects on areas of high desertification risk. Terraced landscape should be managed holistically, in order to establish a sustainable agriculture system, to protect biodiversity and enhance ecosystem services. This study showed that terraces crop production depends strongly on available resources and must be closely linked to site-specific meteorological data, soil profiling, site mapping and precise planning of agricultural activities and crop selection. Moreover, implementation of land stewardship conquers land fragmentation and technological gaps stimulating the involvement of younger generations and overcoming socioeconomic constraints that lead to land abandonment.

Thus, re-cultivation of abandoned lands could be realized under a climate-smart agriculture system encompassing digital technologies, to foster production of added value crops empowering local societies and economies. Land stewardship has a key role to connect actively local communities to safeguard the landesque capital, enhance food security in vulnerable marginal lands strengthening rural development and environment sustainability.

Supplementary Materials: The meteo data from Moustakeio fully automatic weather station are presented on-line, with 30-min interval, at the following WEB page: https:/ /www.iersd.noa.gr/ WeatherOnLine/s_Andros1/meteo_tableEN.html (accessed on 5 April 2021).

Author Contributions: Conceptualisation, P.V.M. and C.G.; methodology, M.S. and B.E.P.; formal analysis, M.S. and B.E.P.; data curation, M.S. and B.E.P.; writing—original draft preparation, M.S. and B.E.P.; writing-review and editing, P.V.M. and C.G.; supervision, P.V.M. All authors have read and agreed to the published version of the manuscript.

Funding: The authors wish to thank the support of EU-LIFE TERRACESCAPE project under the grant agreement LIFE16 CCA/GR/000050.

Institutional Review Board Statement: Not applicable.

Informed Consent Statement: Not applicable.

Data Availability Statement: Meteo data from Moustakeio automatic weather station will be available under request to B.E.P., responsible for the operation of the station and its data arcives.

Acknowledgments: The authors acknowledge John Lemesios for assistance with geographical information systems and software for mapping the study area.

Conflicts of Interest: The authors declare no conflict of interest.

\section{References}

1. Csorba, P. Agriculture: Cultivation on slopes. In Anthropogenic Geomorphology: A Guide to Man-Made Landforms. Available online: https:/ /link.springer.com/chapter/10.1007/978-90-481-3058-0_7 (accessed on 5 April 2021)2010; ISBN 9789048130573.

2. Pérez Rodríguez, V. Terrace Agriculture in the Mixteca Alta Region, Oaxaca, Mexico: Ethnographic and Archeological Insights on Terrace Construction and Labor Organization. Cult. Agric. Food Environ. 2016, 38, 18-27. [CrossRef] 
3. Pietsch, D.; Mabit, L. Terrace soils in the Yemen Highlands: Using physical, chemical and radiometric data to assess their suitability for agriculture and their vulnerability to degradation. Geoderma 2012, 185-186, 48-60. [CrossRef]

4. Kraemer, N.; Dercon, G.; Cisneros, P.; Arango Lopez, F.; Wellstein, C. Adding another dimension: Temporal development of the spatial distribution of soil and crop properties in slow-forming terrace systems. Agric. Ecosyst. Environ. 2019, $283,106543$. [CrossRef]

5. Brandolini, P. The Outstanding Terraced Landscape of the Cinque Terre Coastal Slopes (Eastern Liguria). In World Geomorphological Landscapes; Springer: Berlin/Heidelberg, Germany, 2017; pp. 235-244.

6. Liu, X.; He, B.; Li, Z.; Zhang, J.; Wang, L.; Wang, Z. Influence of land terracing on agricultural and ecological environment in the loess plateau regions of China. Environ. Earth Sci. 2011, 62, 797-807. [CrossRef]

7. Wei, W.; Chen, D.; Wang, L.; Daryanto, S.; Chen, L.; Yu, Y.; Lu, Y.; Sun, G.; Feng, T. Global synthesis of the classifications, distributions, benefits and issues of terracing. Earth-Sci. Rev. 2016, 159, 388-403. [CrossRef]

8. Huang, J.; Zhang, G.; Zhang, Y.; Guan, X.; Wei, Y.; Guo, R. Global desertification vulnerability to climate change and human activities. L. Degrad. Dev. 2020. [CrossRef]

9. El Bilali, H.; Bassole, I.H.N.; Dambo, L.; Berjan, S. Climate change and food security. Agric. For. 2020. [CrossRef]

10. Hussain, M.I.; Muscolo, A.; Farooq, M.; Ahmad, W. Sustainable use and management of non-conventional water resources for rehabilitation of marginal lands in arid and semiarid environments. Agric. Water Manag. 2019, 221, 462-476. [CrossRef]

11. Leal Filho, W.; Mandel, M.; Al-Amin, A.Q.; Feher, A.; Chiappetta Jabbour, C.J. An assessment of the causes and consequences of agricultural land abandonment in Europe. Int. J. Sustain. Dev. World Ecol. 2017. [CrossRef]

12. Kosmas, C.; Kairis, O.; Karavitis, C.; Acikalin, S.; Alcalá, M.; Alfama, P.; Atlhopheng, J.; Barrera, J.; Belgacem, A.; Solé-Benet, A.; et al. An exploratory analysis of land abandonment drivers in areas prone to desertification. Catena 2015. [CrossRef]

13. Subedi, Y.R.; Kristiansen, P.; Cacho, O.; Ojha, R.B. Agricultural Land Abandonment in the Hill Agro-ecological Region of Nepal: Analysis of Extent, Drivers and Impact of Change. Environ. Manag. 2021, 1-19. [CrossRef]

14. Horion, S.; Ivits, E.; De Keersmaecker, W.; Tagesson, T.; Vogt, J.; Fensholt, R. Mapping European ecosystem change types in response to land-use change, extreme climate events, and land degradation. Land Degrad. Dev. 2019. [CrossRef]

15. Salvati, L.; Zitti, M.; Perini, L. Fifty Years on: Long-term Patterns of Land Sensitivity to Desertification in Italy. Land Degrad. Dev. 2016. [CrossRef]

16. Karamesouti, M.; Panagos, P.; Kosmas, C. Model-based spatio-temporal analysis of land desertification risk in Greece. Catena 2018. [CrossRef]

17. Briassoulis, H. Governing desertification in Mediterranean Europe: The challenge of environmental policy integration in multi-level governance contexts. Land Degrad. Dev. 2011. [CrossRef]

18. Karamesouti, M.; Detsis, V.; Kounalaki, A.; Vasiliou, P.; Salvati, L.; Kosmas, C. Land-use and land degradation processes affecting soil resources: Evidence from a traditional Mediterranean cropland (Greece). Catena 2015. [CrossRef]

19. Petanidou, T.; Kizos, T.; Soulakellis, N. Socioeconomic dimensions of changes in the agricultural landscape of the Mediterranean basin: A case study of the abandonment of cultivation terraces on Nisyros Island, Greece. Environ. Manag. 2008. [CrossRef] [PubMed]

20. Van Der Sluis, T.; Kizos, T.; Pedroli, B. Landscape change in Mediterranean farmlands: Impacts of land abandonment on cultivation terraces in Portofino (Italy) and Lesvos (Greece). J. Landsc. Ecol. Repub. 2014. [CrossRef]

21. Boccia, L.; Capolupo, A.; Rigillo, M.; Russo, V. Terrace Abandonment Hazards in a Mediterranean Cultural Landscape. J. Hazard. Toxic Radioact. Waste 2020. [CrossRef]

22. Preti, F.; Errico, A.; Caruso, M.; Dani, A.; Guastini, E. Dry-stone wall terrace monitoring and modelling. L. Degrad. Dev. 2018, 29, 1806-1818. [CrossRef]

23. Tarolli, P.; Preti, F.; Romano, N. Terraced landscapes: From an old best practice to a potential hazard for soil degradation due to land abandonment. Anthropocene 2014, 6, 10-25. [CrossRef]

24. Moreno-de-las-Heras, M.; Lindenberger, F.; Latron, J.; Lana-Renault, N.; Llorens, P.; Arnáez, J.; Romero-Díaz, A.; Gallart, F. Hydro-geomorphological consequences of the abandonment of agricultural terraces in the Mediterranean region: Key controlling factors and landscape stability patterns. Geomorphology 2019, 333, 73-91. [CrossRef]

25. Deng, C.; Zhang, G.; Liu, Y.; Nie, X.; Li, Z.; Liu, J.; Zhu, D. Advantages and disadvantages of terracing: A comprehensive review. Int. Soil Water Conserv. Res. 2021. [CrossRef]

26. Salvati, L.; Kosmas, C.; Kairis, O.; Karavitis, C.; Acikalin, S.; Belgacem, A.; Solé-Benet, A.; Chaker, M.; Fassouli, V.; Gokceoglu, C.; et al. Unveiling soil degradation and desertification risk in the Mediterranean basin: A data mining analysis of the relationships between biophysical and socioeconomic factors in agro-forest landscapes. J. Environ. Plan. Manag. 2015. [CrossRef]

27. Arnaez, J.; Lasanta, T.; Errea, M.P.; Ortigosa, L. Land abandonment, landscape evolution, and soil erosion in a Spanish Mediterranean mountain region: The case of Camero Viejo. Land Degrad. Dev. 2011, 22, 537-550. [CrossRef]

28. Mehmood, M.A.; Ibrahim, M.; Rashid, U.; Nawaz, M.; Ali, S.; Hussain, A.; Gull, M. Biomass production for bioenergy using marginal lands. Sustain. Prod. Consum. 2017. [CrossRef]

29. Schröder, P.; Beckers, B.; Daniels, S.; Gnädinger, F.; Maestri, E.; Marmiroli, N.; Mench, M.; Millan, R.; Obermeier, M.M.; Oustriere, $\mathrm{N}$; ; et al. Intensify production, transform biomass to energy and novel goods and protect soils in Europe-A vision how to mobilize marginal lands. Sci. Total Environ. 2018, 616-617, 1101-1123. [CrossRef] 
30. Longato, D.; Gaglio, M.; Boschetti, M.; Gissi, E. Bioenergy and ecosystem services trade-offs and synergies in marginal agricultural lands: A remote-sensing-based assessment method. J. Clean. Prod. 2019. [CrossRef]

31. Kang, S.; Post, W.M.; Nichols, J.A.; Wang, D.; West, T.O.; Bandaru, V.; Izaurralde, R.C. Marginal Lands: Concept, Assessment and Management. J. Agric. Sci. 2013. [CrossRef]

32. Cots-Folch, R.; Martínez-Casasnovas, J.A.; Ramos, M.C. Land terracing for new vineyard plantations in the north-eastern Spanish Mediterranean region: Landscape effects of the EU Council Regulation policy for vineyards' restructuring. Agric. Ecosyst. Environ. 2006, 115, 88-96. [CrossRef]

33. Neufeldt, H.; Jahn, M.; Campbell, B.M.; Beddington, J.R.; DeClerck, F.; De Pinto, A.; Gulledge, J.; Hellin, J.; Herrero, M.; Jarvis, A.; et al. Beyond climate-smart agriculture: Toward safe operating spaces for global food systems. Agric. Food Secur. 2013. [CrossRef]

34. Lipper, L.; Thornton, P.; Campbell, B.M.; Baedeker, T.; Braimoh, A.; Bwalya, M.; Caron, P.; Cattaneo, A.; Garrity, D.; Henry, K.; et al. Climate-smart agriculture for food security. Nat. Clim. Chang. 2014, 4, 1068-1072. [CrossRef]

35. Campbell, B.M.; Thornton, P.; Zougmoré, R.; van Asten, P.; Lipper, L. Sustainable intensification: What is its role in climate smart agriculture? Curr. Opin. Environ. Sustain. 2014, 8, 39-43. [CrossRef]

36. Shahid, S.A.; Al-Shankiti, A. Sustainable food production in marginal lands-Case of GDLA member countries. Int. Soil Water Conserv. Res. 2013. [CrossRef]

37. Costa, J.M.; Marques da Silva, J.; Pinheiro, C.; Barón, M.; Mylona, P.; Centritto, M.; Haworth, M.; Loreto, F.; Uzilday, B.; Turkan, I.; et al. Opportunities and Limitations of Crop Phenotyping in Southern European Countries. Front. Plant Sci. 2019, 10, 1125. [CrossRef]

38. Tahir, S.; Marschner, P. Clay amendment to sandy soil—effect of clay concentration and ped size on nutrient dynamics after residue addition. J. Soils Sediments 2016. [CrossRef]

39. Rellini, I.; Scopesi, C.; Olivari, S.; Firpo, M.; Maerker, M. Assessment of soil erosion risk in a typical mediterranean environment using a high resolution RUSLE approach (Portofino promontory, NW-Italy). J. Maps 2019. [CrossRef]

40. Stanchi, S.; Freppaz, M.; Agnelli, A.; Reinsch, T.; Zanini, E. Properties, best management practices and conservation of terraced soils in Southern Europe (from Mediterranean areas to the Alps): A review. Quat. Int. 2012. [CrossRef]

41. Debolini, M.; Marraccini, E.; Dubeuf, J.P.; Geijzendorffer, I.R.; Guerra, C.; Simon, M.; Targetti, S.; Napoléone, C. Land and farming system dynamics and their drivers in the Mediterranean Basin. Land Use Policy 2018. [CrossRef]

42. Giordan, D.; Cignetti, M.; Baldo, M.; Godone, D. Relationship between man-made environment and slope stability: The case of 2014 rainfall events in the terraced landscape of the Liguria region (northwestern Italy). Geomat. Nat. Hazards Risk 2017. [CrossRef]

43. Stavi, I.; Rozenberg, T.; Al-Ashhab, A.; Argaman, E.; Groner, E. Failure and collapse of ancient agricultural stone terraces: On-Site effects on soil and vegetation. Water 2018, 10, 1400. [CrossRef]

44. Ackermann, O.; Zhevelev, H.M.; Svoray, T. Agricultural systems and terrace pattern distribution and preservation along climatic gradient: From sub-humid mediterranean to arid conditions. Quat. Int. 2019. [CrossRef]

45. Gardner, R.A.M.; Gerrard, A.J. Runoff and soil erosion on cultivated rainfed terraces in the Middle Hills of Nepal. Appl. Geogr. 2003, 23, 23-45. [CrossRef]

46. Agnoletti, M.; Conti, L.; Frezza, L.; Monti, M.; Santoro, A. Features Analysis of Dry Stone Walls of Tuscany (Italy). Sustainability 2015, 7, 13887-13903. [CrossRef]

47. Raso, E.; Mandarino, A.; Pepe, G.; Calcaterra, D.; Cevasco, A.; Confuorto, P.; Di Napoli, M.; Firpo, M. Geomorphology of Cinque Terre National Park (Italy). J. Maps 2020, 1-14. [CrossRef]

48. Tarolli, P.; Pijl, A.; Cucchiaro, S.; Wei, W. Slope instabilities in steep cultivation systems: Process classification and opportunities from remote sensing. Land Degrad. Dev. 2021, 32, 1368-1388. [CrossRef]

49. Paul, E.A. The nature and dynamics of soil organic matter: Plant inputs, microbial transformations, and organic matter stabilization. Soil Biol. Biochem. 2016, 98, 109-126. [CrossRef]

50. Shahbaz, M.; Kuzyakov, Y.; Sanaullah, M.; Heitkamp, F.; Zelenev, V.; Kumar, A.; Blagodatskaya, E. Microbial decomposition of soil organic matter is mediated by quality and quantity of crop residues: Mechanisms and thresholds. Biol. Fertil. Soils 2017. [CrossRef]

51. Newton, A.C.; Akar, T.; Baresel, J.P.; Bebeli, P.J.; Bettencourt, E.; Bladenopoulos, K.V.; Czembor, J.H.; Fasoula, D.A.; Katsiotis, A.; Koutis, K.; et al. Cereal landraces for sustainable agriculture. A review. Agron. Sustain. Dev. 2010. [CrossRef]

52. Cai, K.; Chen, X.; Han, Z.; Wu, X.; Zhang, S.; Li, Q.; Nazir, M.M.; Zhang, G.; Zeng, F. Screening of Worldwide Barley Collection for Drought Tolerance: The Assessment of Various Physiological Measures as the Selection Criteria. Front. Plant Sci. 2020. [CrossRef]

53. Dawson, I.K.; Russell, J.; Powell, W.; Steffenson, B.; Thomas, W.T.B.; Waugh, R. Barley: A translational model for adaptation to climate change. New Phytol. 2015, 206, 913-931. [CrossRef]

54. Vahamidis, P.; Stefopoulou, A.; Kotoulas, V.; Voloudakis, D.; Dercas, N.; Economou, G. A further insight into the environmental factors determining potential grain size in malt barley under Mediterranean conditions. Eur. J. Agron. 2021. [CrossRef]

55. Cammarano, D.; Hawes, C.; Squire, G.; Holland, J.; Rivington, M.; Murgia, T.; Roggero, P.P.; Fontana, F.; Casa, R.; Ronga, D. Rainfall and temperature impacts on barley (Hordeum vulgare L.) yield and malting quality in Scotland. Field Crops Res. 2019. [CrossRef]

56. Dordas, C. Variation in dry matter and nitrogen accumulation and remobilization in barley as affected by fertilization, cultivar, and source-sink relations. Eur. J. Agron. 2012. [CrossRef] 
57. Kennedy, S.P.; Lynch, J.P.; Spink, J.; Bingham, I.J. Grain number and grain filling of two-row malting barley in response to variation in post-anthesis radiation: Analysis by grain position on the ear and its implications for yield improvement and quality. Field Crops Res. 2018. [CrossRef]

58. Meena, R.S.; Lal, R. Legumes and Sustainable Use of Soils. In Legumes for Soil Health and Sustainable Management; Springer Nature: Singapore, 2018. [CrossRef]

59. Mhadhbi, H.; Mylona, P.V.; Polidoros, A.N. Legume-rhizobia symbiotic performance under abiotic stresses: Factors influencing tolerance behaviour. In Legumes under Environmental Stress: Yield, Improvement and Adaptations; Wiley Blackwell: Hoboken, NJ, USA, 2015; pp. 125-131. [CrossRef]

60. Georgopoulou, E.; Mirasgedis, S.; Sarafidis, Y.; Vitaliotou, M.; Lalas, D.P.; Theloudis, I.; Giannoulaki, K.D.; Dimopoulos, D.; Zavras, V. Climate change impacts and adaptation options for the Greek agriculture in 2021-2050: A monetary assessment. Clim. Risk Manag. 2017. [CrossRef]

61. Sakellariou, M.; Mylona, P.V. New Uses for Traditional Crops: The Case of Barley Biofortification. Agronomy 2020, $10,1964$. [CrossRef]

62. Preissel, S.; Reckling, M.; Schläfke, N.; Zander, P. Magnitude and farm-economic value of grain legume pre-crop benefits in Europe: A review. Field Crops Res. 2015, 175, 64-79. [CrossRef]

63. Hanley, N.; Breeze, T.D.; Ellis, C.; Goulson, D. Measuring the economic value of pollination services: Principles, evidence and knowledge gaps. Ecosyst. Serv. 2015. [CrossRef]

64. Lavrinenko, O.; Ignatjeva, S.; Ohotina, A.; Rybalkin, O.; Lazdans, D. The role of green economy in sustainable development (Case study: The eu states). Entrep. Sustain. Issues 2019. [CrossRef]

65. Barbero-Sierra, C.; Marques, M.J.; Ruíz-Pérez, M. The case of urban sprawl in Spain as an active and irreversible driving force for desertification. J. Arid Environ. 2013. [CrossRef]

66. van Vliet, J.; de Groot, H.L.F.; Rietveld, P.; Verburg, P.H. Manifestations and underlying drivers of agricultural land use change in Europe. Landsc. Urban Plan. 2015, 133, 24-36. [CrossRef]

67. Hartvigsen, M. Land reform and land fragmentation in Central and Eastern Europe. Land Use Policy 2014. [CrossRef]

68. Scown, M.W.; Winkler, K.J.; Nicholas, K.A. Aligning research with policy and practice for sustainable agricultural land systems in Europe. Proc. Natl. Acad. Sci. USA 2019. [CrossRef]

69. Duff, A.J.; Zedler, P.H.; Barzen, J.A.; Knuteson, D.L. The capacity-building stewardship model: Assessment of an agricultural network as a mechanism for improving regional agroecosystem sustainability. Ecol. Soc. 2017. [CrossRef]

70. García-Martín, M.; Plieninger, T.; Bieling, C. Dimensions of landscape stewardship across Europe: Landscape values, place attachment, awareness, and personal responsibility. Sustainability 2018, 10, 263. [CrossRef]

71. Heider, K.; Rodriguez Lopez, J.M.; Balbo, A.L.; Scheffran, J. The state of agricultural landscapes in the Mediterranean: Smallholder agriculture and land abandonment in terraced landscapes of the Ricote Valley, southeast Spain. Reg. Environ. Chang. 2021, 21, 1-12. [CrossRef]

72. Koohafkan, P.; Altieri, M.A. Globally Important Agricultural Heritage System: A Legacy for the Future; Food and Agriculture Organaization of the United Nations: Rome, Italy, 2011.

73. Slámová, M.; Jakubec, B.; Hreško, J.; Beláček, B.; Gallay, I. Modification of the potential production capabilities of agricultural terrace soils due to historical cultivation in the Budina cadastral area, Slovakia. Morav. Geogr. Rep. 2015. [CrossRef]

74. Yongxun, Z.; Qingwen, M.; Wenjun, J.; Moucheng, L. Values and Conservation of Honghe Hani Rice Terraces System as a GIAHS Site. J. Resour. Ecol. 2016. [CrossRef]

75. Santoro, A.; Venturi, M.; Agnoletti, M. Agricultural heritage systems and landscape perception among tourists. The case of Lamole, Chianti (Italy). Sustainability 2020, 12, 3509. [CrossRef]

76. Kizos, T.; Koulouri, M.; Vakoufaris, H.; Psarrou, M. Preserving characteristics of the agricultural landscape through agrienvironmental policies: The case of cultivation terraces in Greece. Landsc. Res. 2010. [CrossRef] 